\title{
БІОТЕХНОЛОГІЧН ОСНОВИ ТЕХНОЛОГІЇ КОНСТРУЮВАННЯ «GREЕN ARTICLE» ДЛЯ УПРАВЛІННЯ ХАРАКТЕРИСТИКАМИ БІОКЕРАМІЧНОГО ЗАХИСНОГО ШАРУ ШКАРАЛУПИ ЯЄЦЬ КУРЕЙ В ТЕХНОЛОГІЧНОМУ ПРОЦЕСІ ІНКУБАЦІЇ
}

Бордунова Ольга Георгіївна доктор сільськогосподарських наук, профессор Сумський національний аграрний університет

ORCID: 0000-0002-7120-1040 E-mail: bordunova.olga59@gmail.com

Самохіна Євгенія Анатоліївна кандидат сільськогосподарських наук, доцент Сумський національний аграрний університет ORCID: 0000-0002-0983-3047

E-mail: f_bt@sau.ua

Хмельничий Леонтій Михайлович доктор сільськогосподарських наук, професор Сумський національний аграрний університет ORCID: 0000-0001-5175-1291 E-mail: khmelnychy@ukr.net

Повод Микола Григорович доктор сільськогосподарських наук, професор Сумський національний аграрний університет ORCID: 0000-0001-9272-9672

E-mail: snau.cz@ukr.net

Вечорка Вікторія Вікторівна, д доктор сільськогосподарських наук, професор Сумський національний аграрний університет ORCID: 0000-0003-4956-2074 E-mail: vvvechorka@gmail.com

Попсуй В'ячеслав Васильович кандидат сільськогосподарських наук, доцент Сумський національний аграрний університет ORCID: 0000-0002-3487-0923

E-mail: $\underline{\text { VP72@ukr.net }}$

Авторами теоретично обгрунтована та практично доведена ефективність застосування розробленого способу передінкубаційної обробки яєць з використанням біоміметичної технології «штучна кутикула» «ARTICLE» («ARTIficial cutiCLE») «GREEN ARTICLE» для поліпшення структурних і фізіологічних характеристик шкаралупи як біокерамічного захисного шару інкубаційних яєць, котра полягає в утворенні на поверхні яйця захисної плівки з суміші штучних і природних матеріалів, що регулює рівень газопроникності шкаралупи пташиного яйця. Захисна плівка являє собою полікомпонентне покриття для відновлення та посилення бар'єрних властивостей біокерамічних структур шкаралупи і шкаралупних мембран, якому притаманна біоцидна (антибактеріальна та антивірусна) активність, а також здатність оптимізувати газообмін ембріонів протягом інкубації та поліпшувати процеси обміну речовин ембріона і якість молодняка птиці. Метою нашої роботи була розробка технології передінкубаційної обробки курячих яєць «GREEN ARTICLE» з використанням захисних нанокомпозитних покриттів "Штучна кутикула», що були створені за біоміметичним принципом, для зниження контамінації патогенною мікрофрлорою та підвищення виводимості яєць. Для проведення досліду було сфрормовано три партії яєць, котрі були отримані від курей-несучок Легорн білий, по 540 штук в кожній групі. В кожній партії був контроль і дослідна група. Інкубацію проводили в інкубаторі «Універсал» протягом 21 доби згідно методики. Першу групу яєць перед закладкою на інкубацію обробляли кислото розчинним хітозаном, другу - водорозчинним хітозаном, третю - водорозчинним хітозаном сукцинат. Рахували відсоток браку інкубації, вивід та виводимість курчат. Перед закладкою на інкубацію, а також на сьому та вісімнадияту добу інкубації, перед перенесенням яєць у вивідну шафу, брали змиви з поверхні шкаралупи і досліджували їх на наявність мікробної контамінації. Доведено, що використання для передінкубаційної дезінфекції курячих яєць композиції на основі кислоторозчинного хітозана з додаванням надоцтової кислоти, пероксиду водню $\left(\mathrm{H}_{2} \mathrm{O}_{2}\right)$ та наночасток металів (нанодисперсного діоксиду титану $\mathrm{TiO}_{2}$, оксиду заліза $\mathrm{Fe}_{2} \mathrm{O}_{3}$ та сульсрату міді $\mathrm{CuSO}_{4}$ ), стимулює розвиток 
ембріонів та забезпечує підвищення виводимості яєць на 7,7 \% відносно контролю. Технологія «GREEN ARTICLE» для передінкубаційної обробки яєць з використанням препарату «Штучна кутикула» призводить до значного зниження кількості патогенних мікроорганізмів на поверхні шкаралупи, що призводить до підвищення виводимості яєць.

Ключові слова: біотехнологія, технологія, хітозан, нанотехнології, інкубація яєць, дезінфектанти.

DOI: https://doi.org/10.32845/bsnau.lvst.2020.3.5

Постановка проблеми, аналіз останніх досліджень, актуальність та мета

В сучасному птахівництві, як і в інших галузях тваринництва, використовується досить великий арсенал сануючих засобів і дезінсректантів різної хімічної природи і механізму дії (луги, кислоти, препарати хлору, йоду, формальдегід, а також продукти нафртопереробки - креолін, лізол, нафтта лізол, креОзот тощо) (Б. Т. Стегній, 2005; В. О. Бреславець, 2006; M. Balaz, 2014; M. Yuceer, 2014; D'Alba et al., 2016) $[4,9,12,15,24]$. Однак, використання зазначених дезінфектантів у птахівництві не завжди виправдане, оскільки не забезпечує бажаного успіху санування. Зокрема, використання для дезінфекції інкубаційних яєць лугів, йодинолу або формальдегіду призводить до інактивації кутикули - природного зовнішнього захисного бар'єру яйця, вагомою складовою котрого $€$ лізоцим. Порушення кутикули, в свою чергу, індукує зниження щільності нижче локалізованих захисних бар'єрів яйця, а саме шкаралупи та підшкаралупних оболонок, що загалом призводить до суттєвого зниження ступеня резистентності ембріона до патогенної мікрофрлори та впливу інших біотичних та абіотичних чинників довкілля. Виходячи з цього, зазначені дезінфектанти рекомендовано використовувати лише для обробки інвентарю та конструкційних елементів птахівницьких приміщень. В останні часи в промисловому птахівництві використовують дезінфектанти на основі четвертинних амонієвих сполук (ЧАС) $[1,6,8,10]$. Такі дезінфікуючі засоби мають мембрано атакуючі властивості щодо пригнічення мікроорганізмів. Вони руйнують біополімери клітинної мембрани, в наслідок чого гинуть мікробні клітини. Четвертинні амонієві сполуки належать до поверхнево-активних речовин. Вони $є$ антистатиками та кондиціонерами, активні проти грибів, бактерій і вірусів. Мають піноутворюючу та миючу властивість. Після висихання розчину ЧАС на гладких поверхнях утворюється тонка, невидима плівка. До таких препаратів відноситься ATM, Пербаксан, CID 20, Virocid тощо. Зазначеним речовинам та композиціям притаманні певні недоліки. Препарати для захисту інкубаційних яєць, до складу яких входять четвертинні амонієві сполуки не $є$ екологічно безпечними внаслідок деструктивної дії корисної мікрофрлори довкілля. У патогенної мікрофрлори розвивається резистентність до таких препаратів, плівки, що утворюють сполуки четвертинного амонію не $€$ газопроникними, через це використання таких препаратів потребує строго дотримання технології обробки $[1,5,7,11,13]$.

Науковці різних країн вишукують нові технології удосконалення інкубації яєць (M. Balaz, 2014; D'Alba et al., 2016;
V. C. Gole et al. 2014, ; M. Yuceer, 2014; Б. Т. Стегній, 2005; B. О. Бреславець, 2006)[12,16,17,24]. Розроблені нові підходи для подолання негативних тенденцій в сучасному племінному птахівництві. Одним з перспективних напрямків $є$ розробка нових технологій інкубації за біоміметичним (biomimetics, від bios - життя, mimesis - подібність) принципом. Основою такої технології $€$ імітування природних структур клітин, тканин або органів, використовуючи натуральні та штучні речовини 3 метою досягнення максимального рівня подібності структурних та функціональних характеристик штучних об'єктів до природних (Muzzarelli R.A.A., 2014; Yu Shao et al., 2015; Liu Z. et al., 2016; D'Alba et al., 2016) $[19,21,23,25]$. Тak, прикладом розробленої біоміметичної технології являється технологія «штучної кутикули» («ARTIficial cutiCLE» «GREEN ARTICLE» для інкубаційних яєць. Вона полягає в утворенні на поверхні яйця штучної захисної плівки, що подібна за структурно-функціональними характеристиками до природної кутикули шкаралупи пташиних яєць (Chen S.P., 2015; Xiao Wei, 2013; D’Alba L., 2014; Gang Xiao et al., 2015) [18,20,22].

Базовою ідеєю нашої роботи була гіпотеза щодо конструювання аналога кутикули як природного захисного шару пташиних яєць 3 притаманними антибактеріальними і противірусними властивостями та здатністю до ефеективного регулювання обміну речовин ембріону протягом інкубації на основі біоміметичного підходу з використанням методів екологічно безпечної «зеленої» хімії та широко розповсюджених у природі нетоксичних і недорогих речовин на зразок хітину $[2,3,14]$.

Метою роботи була розробка технології передінкубаційної обробки курячих яєць 3 використанням захисних нанокомпозитних покриттів «штучна кутикула» «GREEN ARTICLE», що були створені за біоміметичним принципом, для зниження контамінації патогенною мікрофлорою та підвищення виводимості яєць.

Матеріали та методи досліджень. Для проведення досліду було сформовано три партії яєць, котрі були отримані від курей-несучок Легорн білий, по 540 штук в кожній групі. В кожній партії був контроль і дослідна група. Інкубацію проводили в інкубаторі «Універсал» протягом 21 доби згідно методики. Першу групу яєць перед закладкою на інкубацію обробляли кислото розчинним хітозаном, другу - водорозчинним хітозаном, третю - водорозчинним хітозаном сукцинат. Контрольні групи яєць обробляли фумігацією формальдегіду. Рахували відсоток браку інкубації, вивід та виводимість яєць. Досліди проводили за наступною схемою (Табл. 1). 
Схема проведення досліду

\begin{tabular}{|c|c|c|c|}
\hline Партія & Група & Препарат & Метод обробки \\
\hline \multirow[t]{2}{*}{1} & Контроль & Пара формальдегіду & Фумігація формальдегіду \\
\hline & Дослід 1 & $\begin{array}{l}\text { Розчин хітозану кислоторозчинного }+\mathrm{HOK}+\mathrm{Fe}_{2} \mathrm{O}_{3}+\mathrm{TiO}_{2}+ \\
\qquad \mathrm{H}_{2} \mathrm{O}_{2}+\mathrm{CuSO}_{4}\end{array}$ & $\begin{array}{l}\text { Обприскування за допомогою } \\
\text { розпилювача типу «Росинка» }\end{array}$ \\
\hline \multirow[t]{2}{*}{2} & Контроль & Пара формальдегіду & Фумігація формальдегіду \\
\hline & Дослід 2 & $\begin{array}{c}\text { Розчин хітозану водорозчинного }+\mathrm{HOK}+\mathrm{Fe}_{2} \mathrm{O}_{3}+\mathrm{TiO}_{2}+\mathrm{H}_{2} \mathrm{O}_{2}+ \\
\mathrm{CuSO}_{4}\end{array}$ & $\begin{array}{l}\text { Обприскування за допомогою } \\
\text { розпилювача типу «Росинка» }\end{array}$ \\
\hline \multirow[t]{2}{*}{3} & Контроль & Пара формальдегіду & Фумігація формальдегіду \\
\hline & Дослід 3 & $\begin{array}{c}\text { Розчин хітозану водорозчинного (сукцинат)+HOK }+\mathrm{Fe}_{2} \mathrm{O}_{3}+ \\
\qquad \mathrm{TiO}_{2}+\mathrm{H}_{2} \mathrm{O}_{2}+\mathrm{CuSO}_{4}\end{array}$ & $\begin{array}{l}\text { Обприскування за допомогою } \\
\text { розпилювача типу «Росинка» }\end{array}$ \\
\hline
\end{tabular}

Перед закладкою на інкубацію, а також на сьому та вісімнадцяту добу інкубації, перед перенесенням яєць у вивідну шафу, брали змиви з поверхні шкаралупи і досліджували їх на наявність мікробної контамінації. Дослідження проводили згідно ДСТУ 4769:2007 «Яйця курячі харчові. Технічні умови». Проби для хімічних і мікробіологічних аналізів відбирали згідно з ГОСТ 30364.0. 10.7.

Результати досліджень. При створенні препарату спочатку досліджували взаємодію хітозану різної хімічної природи - хітозану кислоторозчинного, хітозану водорозчинного та хітозану сукцінату водорозчинного. В композиції препаратів вносили пероксидні речовини, оцтову та надоцтову кислоти, а також наночастки різних металів. Додавали нано дисперсний оксид заліза $\left(\mathrm{Fe}_{2} \mathrm{O}_{3}\right)$, сульфат міді $\left(\mathrm{CuSO}_{4}\right)$ та діоксид титану $\left(\mathrm{TiO}_{2}\right)$

В результаті досліджень встановлено сумарний вплив потужного окислювача надоцтової кислоти і нанодисперсного діоксиду титану, оксиду заліза і сульфату міді разом з кислоторозчинним хітозаном, що слугує матричною речовиною композиції «GREEN ARTICLE». Природний біополімер хітозан за своею природою має незначну біоцидну активність, але в комплексі з пероксидними речовинами та наночастками металів проявляє потужну протибактеріальну, противірусну та фунгіцидну дію. Хітозан $є$ нетоксичною та екологічно безпечною речовиною.

Захисний ефект композиції «GREEN ARTICLE» полягає в наступному: на поверхні шкаралупи інкубаційного яйця утворюється тонка газопроникна плівка, що має розміри 0,055,0 мкм; водний розчин препарату захищає кутикулу шкаралупи від просочування і надходження надоцтової кислоти в середину інкубаційного яйця; біоцидний ефект проявляється завдяки бактерицидності хітозану та фото каталітичних властивостей оксидів металів, що входять до складу препарату; така дія оксидів металів призводить до поліпшення газообміну ембріона.

Нашими дослідами було встановлено, що використання технології «GREEN ARTICLE» з передінкубаційною обробкою композиції на основі кислото розчинного хітозану та наночасток металів дозволяє знизити обсіменіння шкаралупи патогенними мікроорганізмами, зменшити відходи інкубації та підвищити виводимість яєць курей (табл. 2).

\section{Ефективність передінкубаційної обробки яєць курей препаратами} на основі хітозану різної хімічної природи, $\overline{X \pm} S_{\bar{x}}$

\begin{tabular}{|c|c|c|c|c|}
\hline \multirow[t]{2}{*}{ Методи обробки } & \multirow[t]{2}{*}{$\begin{array}{l}\text { Виводимість } \\
\text { яєць, \% }\end{array}$} & \multirow[t]{2}{*}{$\begin{array}{l}\text { Відходи } \\
\text { інкубації, \% }\end{array}$} & \multicolumn{2}{|c|}{$\begin{array}{c}\text { Рівень мікробної контамінації поверхні } \\
\text { шкаралупи яєць на } 18 \text { добу після } \\
\text { обробки } \\
\end{array}$} \\
\hline & & & бактерії, КУО & гриби, колоній \\
\hline Контроль (формальдегід) & $86,5 \pm 1,46$ & $20,4 \pm 0,27$ & $83,7 \pm 8,024$ & $126 \pm 0,23$ \\
\hline $\begin{array}{l}\text { Розчин хітозану кислоторозчинного }+\mathrm{HOK}+\mathrm{H}_{2} \mathrm{O}_{2}+\mathrm{Fe}_{2} \mathrm{O}_{3}+\mathrm{TiO}_{2}+ \\
\mathrm{CuSO}_{4}\end{array}$ & $94,2 \pm 0,35$ & $5,1 \pm 0,07$ & $32,24 \pm 0,008^{*}$ & - \\
\hline Розчин хітозану сукцинату $+\mathrm{HOK}+\mathrm{H}_{2} \mathrm{O}_{2}+\mathrm{Fe}_{2} \mathrm{O}_{3}+\mathrm{TiO}_{2}+\mathrm{CuSO}_{4}$ & $92,3 \pm 1,06$ & $6,6 \pm 1,04$ & $44,15 \pm 4,022$ & $0,3 \pm 0,06$ \\
\hline Розчин хітозану водорозчинного $+\mathrm{HOK}+\mathrm{H}_{2} \mathrm{O}_{2}+\mathrm{Fe}_{2} \mathrm{O}_{3}+\mathrm{TiO}_{2}+\mathrm{CuSO}_{4}$ & $91,4 \pm 2,17$ & $9,6 \pm 0,04$ & $56,61 \pm 2,012$ & $11 \pm 0,02$ \\
\hline
\end{tabular}

Примітка. * $-p<0,05$

На результати інкубації та рівень мікробного обсіменіння поверхні шкаралупи яєць кращий вплив здійснює метод передінкубаційної обробки яєць розчином, до складу якого входять інгредієнти: кислото розчинний хітозан $+\mathrm{HOK}+\mathrm{H}_{2} \mathrm{O}_{2}$ $+\mathrm{Fe}_{2} \mathrm{O}_{3}+\mathrm{TiO}_{2}+\mathrm{CuSO}_{4}$. Виводимість яєць при даній обробці збільшується на 7,7 \% відносно контролю.

В той же час, використання у технології «GREEN ARTICLE» в якості базової «матриксної» речовини хітозану водо розчинного поступається за кінцевими результатами відповідним дослідам із хітозаном кислото розчинним.

Отже, розроблена за біоміметичним принципом технологія «GREEN ARTICLE» з використанням для передінкубаційної обробки яєць курей композиція «Штучна кутикула» створює подібну за структурними та функціональними параметрами до природної кутикули полі компонентне покриття для захисту та підсилення бар'ерних властивостей біокерамічних структур шкаралупи та її мембран.

Висновки. 1. Використання для передінкубаційної дезінфекції курячих яєць композиції на основі кислоторозчинного хітозана з додаванням надоцтової кислоти, пероксиду водню $\left(\mathrm{H}_{2} \mathrm{O}_{2}\right)$ та наночасток металів (нанодисперсного діоксиду титану $\mathrm{TiO}_{2}$, оксиду заліза $\mathrm{Fe}_{2} \mathrm{O}_{3}$ та сульфату міді $\mathrm{CuSO}_{4}$ ), стимулює розвиток ембріонів та забезпечує підвищення виводимості яєць на 7,7 \% відносно контролю.

2. Технологія «GREEN ARTICLE» для передінкубаційної обробки яєць 3 використанням препарату «Штучна кутикула» призводить до значного зниження кількості патогенних мікроорганізмів на поверхні шкаралупи, що призводить до підвищення виводимості яєць. 
Подяки. Робота виконана за фінансової підтримки Міністерства освіти і науки України (номер державної реєстрації 0119U100551).

\section{Список використаної літератури}

1. Бессарабов Б. Ф. Инкубация яиц с основами эмбриологии сельскохозяйственной птицы. М: Колос. 2006. С. 264.

2. Бордунова О. Г. Біометрична технологія захисту інкубаційних яєць курей з використанням нанокомпозитів хітозану і діоксиду титана. Таврійський науковий вісник. Херсон. Айлант. 2008. Вип.56. С. 104-115.

3. Бордунова О. Г. Нанокомпозит хітозану і діоксину титану у біоміметичній технології захисту інкубаційних яєць сільськогосподарської птиці. Міжвідомчий тематичний науковий збірник Птахівництво. Бірки. 2010. Вип. 65. С. 116-127.

4. Бреславець В. О. Дослідження газо- та вологопроникності шкаралупи яєць курей різних порід та віку. Птахівництво : міжвід. темат. наук. зб. ІП УААН. 2006. № 58. С. 355-360.

5. Бреславець В. О. Інкубація яєць сільськогосподарської птиці : методичний посібник. Х. : ІЕіКВМ. 2001. С. 92.

6. Медведев А. Безопасные средства для дезинфекции. Птицеводство. 2001. № 4. С. 37-41.

7. Прокудина Н. А. Инкубация яиц сельскохозяйственной птицы. Х.: «НТМТ», 2008. С. 386.

8. Сахацький І. Дезінфекційні засоби для птахівництва: порівняльна ефрективність. Ветеринарна медицина України. 2005.№ 1. С. 40-43.

9. Стегній Б. Т. Порівняльна оцінка препаратів для передінкубаційної обробки яєць. Міжнародний тематичний науковий збірник. Харків. 2005. Т. 2. № 85. С. 1022-1025.

10. Якубчак О. М. Чим краще обробити? Порівняльна оцінка сучасних і традиційних дезінфекційних засобів, що використовуються в галузі птахівництва. Сучасне птахівництво. 2006. № 6. С. 14-15.

11. Wei Xiao, Junbo Xu, Xiaoyan Liu, Qiaoling Hub and Jianguo Huang.Antibacterial hybrid materials fabricated by nanocoating of microfibril bundles of cellulose substance with titania /chitosan/silver-nanoparticle composite films. J. Mater. Chem. B, 2013, issue 1, pp. 34773485.

12. Balaz M. Eggshell membrane biomaterial as a platform for applications in materials science. Acta Biomaterialia. 2014. V. 10, issue 9, pp. 3827-3843. doi: 10.1016/j.actbio.2014.03.020.

13. Bain M. M., Mcdade K. and Burchmore R. Enhancing the egg's natural defence against bacterial penetration by increasing cuticle deposition. Animal Genetics. 2013. V 44, issue 6, pp. 661-668. doi: 10.1111/age.12071.

14. Bordunova O. G. Study of the correlations between the dynamics of thermal destruction and the morphological parameters of biogenic calcites by the method of thermoprogrammed desorption mass spectrometry (TPD-MS) / Bordunova O. G., Samokhina Y. A., Loboda V. B., Chernenko O. M., Dolbanosova R. V., Chivanov V. D. // Springer Proceedings in Physics, Springer, Singapore, 2020, issue 240. p. 37-50. https://doi.org/10.1007/978-981-15-1742-6

15. D'Alba L., Jones D. N. and Badawy H. T. Antimicrobial properties of a nanostructured egg shell from a compost-nesting bird. Journal of Experimental Biology. 2014. Issue 217 (7), pp. 1116-1121.

16. D’Alba L., Maia R. and Hauber M. E. Evolution of avian eggshell structure in relation to nesting ecology. Proc. R. Soc. Lond. B. 2016. V. 283: 20160687.doi: 10.1098/rspb.2016.0687.

17. Gole V. C., Roberts J. R. and Sexton M. Effect of egg washing and correlation between cuticle and egg penetration by various Salmonella strains. International Journal of Food Microbiology. 2014. issue. 182-183, pp. 18-25. doi: j. ijfoodmicro.2014.04.030.

18. Gang Xiao. Synthesis of core-shell bio a finity chitosan- $\mathrm{TiO}_{2}$ composite and its tnviron mental applications. Journal of Hazardous Materials. 2015.issue 283, pp. 888-896.

19. Su Hyun Kim, Hong Kyo on No and Witoon Prinyawiwatkul. Effect of Molecular weight, type of chitosan, and chitosan solution pH on the shelf-life and quality of coated eggs, Journal of food science.2007. Vol. 72, issue 1, pp. 44-48.

20. Bain M. M., Mc dad K. and Burchmore R. Enhancing the egg's natural defence against bacterial penetration by increasing cuticle deposition. Animal Genetics. 2013. DOI: 10.1111. - age. 12071.

21. Liu Z., Sun X. and Cai C. Characteristics of glycosaminoglycans in chicken eggshells and the influence of disaccharide composition on eggshell properties. Poultry Science. 2016. V. 95, issue 12, pp. 2879-2888. doi: 10.3382/ ps /pew179.

22. Maria P., Montero Garcia, M. Carmen G., M. Elvira L., Gustavo V. Edible films and coatings: fundamentals and applications. CRC Press, Taylor \& Francis Group. 2017. pp. 598.

23. Maureen B., Yves N. and Filip V. Immerseel food science, technology and nutrition improving the safety and quality of eggs and egg products: Volume 2: Egg safety and nutritional quality. Woodhead Publishing. 2011. pp. 448.

24. Yuceer M., Caner C. Antimicrobial lysozyme-chitosan coatings affect unctional properties and shelf life of chicken eggs during storage // J. Sci. Food Agric. 2014. Issue 94, pp.153-162. doi: 10.1002/jsfa.6322.

25. Yu Shao, Changsheng Cao and Shiliang Chen Investigation of nitrogen doped and carbon species decorated $\mathrm{TiO}_{2}$ with enhanced visible light photocatalytic activity by using chitosan. Applied Catalysis B: Environmental.2015. issue 179, pp. 344-351.

\section{References:}

1. Bessarabov, B. F., 2006. Inkubatsiya yaits s osnovami embriologi selskohozyaystvennoy ptitsyi [Incubation of eggs with the basics of poultry embryology]. M: Kolos, pp. 264.

2. Bordunova, O. H. 2008. Biometrychna tekh nolohiiazakhystu inkubatsiinykhyaiets kurei z vykorystanniam nanokompozytiv khitozanu i dioksyduty titana [Biometric technology for protection of hatching eggs of chickens using nanocomposites of chitosan and titanium dioxide]. Tavriiskyinaukovyivisnyk. Kherson. Ailant, issue. 5, pp. 104-115. 
3. Bordunova, O. H., 2010. Nanokompozyt khitozanu i dioksynu tytanu u biomimetychni i tekhnolohii zakhystu inkubatsiinykh yaiets silskohospodarskoi ptytsi [Nanocomposite of chitosan and titanium dioxin in biomimetic technology of protection of hatching eggs of poultry]. Mizhvidomchyi tematychnyi naukovyi zbirnyk Ptakhivnytstvo. Birky ,issue.65, pp. 116-127.

4. Breslavets, V. O., 2006. Doslidzhennia hazo- ta volohopronyknosti shkaralupy yaiets kurei riznykh porid ta viku [Investigation of gas and moisture permeability of eggshells of chickens of different breeds and ages]. Ptakhivnytstvo : mizhvid. temat. nauk. zb. IP UAAN, issue 58, pp. 355-360.

5. Breslavets, V. O., 2001. Inkubatsiia yaiets silskohospodarskoi ptytsi : metodychnyi posibnyk [Incubation of poultry eggs: a guide]. Kh: IEIKVM. pp. 92.

6. Medvedev, A., 2001. Bezopasnyie sredstva dlya dezinfektsii [Safe disinfectants]. Ptitsevodstvo, issue 4. pp. 37-41.

7. Prokudina, N. A., 2008. Inkubatsiya yaits selskohozyaystvennoy ptitsyi [Incubation of poultry eggs]. H.: «NTMT», pp. 386.

8. Sakhatskyi, I., 2005. Dezinfektsiini zasoby dlia ptakhivnytstva: porivnialna efektyvnist [Disinfectants for poultry: comparative effectiveness]. Veterynarna medytsyna Ukrainy, issue 1, pp. 40-43.

9. Stehnii, B. T., 2005. Porivnialna otsinka preparative dlia peredinkubatsiinoi obrobky yaiets [Comparative evaluation of drugsforpre-incubation treatment of eggs]. Mizhnarodnyi tematychnyi naukovyi zbirnyk. Kharkiv. T. 2, issue 85, pp. 1022-1025.

10. lakubchak, O. M., 2006. Chym krashche obrobyty? Porivnialna otsinka suchasny khitradytsii nykhde zinfektsiin ykhzasobiv, shcho vykorystovuiutsia $v$ haluzi ptakhivnytstva [What is more beautiful to grind? Ratio assessment of the occasional and traditional disinfectious diseases, how to get sick in the branch poultry]. Suchasne ptakhivnytstvo, issue 6. pp. 14-15.

11. Wei Xiao, Junbo Xu and Xiaoyan Liu., 2013. Antibacterial hybrid materials fabricated by nanocoating of microfibril bundles of cellulose substance with titania / chitosan / silver-nanoparticle composite films. J. Mater. Chem. B., issue 1, pp. 34773485.

12. Balaz, M., 2014. Eggshell membrane biomaterial as a platform for applications in materials science. Acta Biomaterialia. V. 10, issue 9, pp. 3827-3843. Doi :10.1016/j.actbio.2014.03.020.

13. Bain, M. M., Mcdade, K. and Burchmore, R., 2013. Enhancing the egg's natural defence against bacterial penetration by increasing cuticle deposition. Animal Genetics. V 44, issue 6, pp. 661-668. Doi: 10.1111/age.12071.

14. Bordunova, O. G., 2020. Study of the correlations between the dynamics of thermal destruction and the morphological parameters of biogenic calcites by the method of thermoprogrammed desorption mass spectrometry (TPD-MS) / Bordunova, O. G. Samokhina Y. A., Loboda, V. B., Chernenko, O M., Dolbanosova, R. V., Chivanov, V. D. // Springer Proceedings in Physics, Springer, Singapore, issue 240. pp. 37-50. https://doi.org/10.1007/978-981-15-1742-6

15. D'Alba, L., Jones, D. N. and Badawy, H. T., 2014. Antimicrobial properties of a nanostructured egg shell from a compostnestingbird. Journal of Experimental Biology, issue 217(7), pp. 1116-1121.

16. D’Alba, L., Maia, R. and Hauber, M. E., 2016 Evolution of avian eggshell structure in relation to nesting ecology. Proc. R. Soc. Lond. B. V. 283: 0687. doi: 10.1098/rspb.2016.0687.

17. Gole, V. C., Roberts, J. R. and Sexton, M., 2014. Effect of egg washing and correlation between cuticle and egg penetration by various Salmonella strains. International Journal of Food Microbiology, issue. 182-183, pp. 18-25. doi: j. ijfoodmicro.2014.04.030.

18. Gang, Xiao., 2015. Synthesis of core-shell bioaffinity chitosan- $\mathrm{TiO}_{2}$ composite and its tnvironmental applications. Journal of Hazardous Materials, issue 283, pp. 888-896.

19. Su, Hyun Kim, Hong, Kyoon, No and Witoon Prinyawiwatkul., 2007. Effect of Molecular weight, type of chitosan, and chitosan solution pH on the shelf-life and quality of coated eggs, Journal of food science. Vol. 72, issue 1, pp. 44-48.

20. Bain, M. M., Mcdade, K. and Burchmore, R., 2013 Enhancing the egg's natural defence against bacterial penetration by increasing cuticle deposition. Animal Genetics.DOI: 10.1111. - age. 12071.

21. Liu, Z., Sun, X. and Cai, C., 2016. Characteristics of glycos aminoglycans in chicken eggshells and the influence of disaccharide composition on eggshell properties. Poultry Science. V. 95, issue 12, pp. 2879-2888. doi: 10.3382/ ps /pew179.

22. Maria, P., Montero Garcia, M. and Carmen, G., V., 2017. Edible films and coatings: fundamentals and applications.CRC Press, Taylor \& Francis Group. pp. 598.

23. Maureen, B., Yves, N. and Filip, V., 2011. Immerseel food science, technology and nutrition improving the safety and quality of eggs and egg products: Volume 2: Egg safety and nutritional quality. Woodhead Publishing. pp. 448.

24. Yuceer, M., Caner, C., 2014 Antimicrobial lysozyme-chitosan coatings affect unctional properties and shelf life of chicken eggs during storage. J. Sci. Food Agric, issue 94, pp.153-162. doi: 10.1002/jsfa.6322.

25. Yu, Shao, Changsheng, Cao and Shiliang, Chen, 2015. Investigation of nitrogen doped and carbon species decorated $\mathrm{TiO}_{2}$ with enhanced visible light photocatalytic activity by using chitosan. Applied Catalysis B: Environmental, issue 179, pp. 344-351.

Bordunova Olga Georgievna, Doctor of Agricultural Sciences, Professor

Samokhina Evgeniya Anatoliyivna, Ph.D. of Agricultural Sciences

Khmelnychyi Leontiy Mykhailovych, Doctor of Agricultural Sciences, Professor

Povod Mykola Hryhorovych, Doctor of Agricultural Sciences, Professor

Vechorka Victoria Viktorivna, Doctor of Agricultural Sciences, Professor

Popsuy Vyacheslav Vasilyevich, Ph.D. of Agricultural Sciences

Sumy National Agrarian University (Sumy, Ukraine)

Biotechnological bases of design technology "green article" for control of characteristics of bioceramic protective layer of eggs shell of hens in technological process of incubation

The authors theoretically substantiated and practically proved the effectiveness of the developed method of pre-incubation treatment of eggs using biomimetic technology "artificial cuticle" "ARTICLE" ("ARTIficial cutiCLE") "GREEN ARTICLE" to improve the 
structural and physiological characteristics of the shell as a bioceramic shell. in the formation on the surface of the egg of a protective film of a mixture of artificial and natural materials, which regulates the level of gas permeability of the bird's egg shell. The protective film is a multicomponent coating to restore and enhance the barrier properties of the bioceramic structures of the shell and shell membranes, which has biocidal (antibacterial and antiviral) activity, as well as the ability to optimize embryo gas exchange during incubation and improve fertilization processes. The aim of our work was to develop the technology of pre-incubation treatment of chicken eggs "GREEN ARTICLE" using protective nanocomposite coatings "Artificial Cuticle", which were created on a biomimetic basis, to reduce contamination with pathogenic microflora and increase hatchability of eggs. For the experiment, three batches of eggs were formed, which were obtained from laying hens Legorn white, 540 pieces in each group. Each batch had a control and an experimental group. Incubation was performed in an incubator "Universal" for 21 days according to the method. The first group of eggs before laying for incubation was treated with acid-soluble chitosan, the second - water-soluble chitosan, the third - water-soluble chitosan succinate. The percentage of lack of incubation, hatching and hatching of chickens was calculated. Before laying for incubation, as well as on the seventh and eighteenth day of incubation, before transferring the eggs to the hatch, took washings from the surface of the shell and examined them for microbial contamination. It is proved that the use for pre-incubation disinfection of chicken eggs of a composition based on acid-soluble chitosan with the addition of peracetic acid, hydrogen peroxide $\left(\mathrm{H}_{2} \mathrm{O}_{2}\right)$ and metal nanoparticles (nanodisperse titanium dioxide $\mathrm{TiO}_{2}$, iron oxide $\mathrm{Fe}_{2} \mathrm{O}_{3}$ and copper sulfateCuSO 4 ), stimulates the development of by $7,7 \%$ relative to control. GREEN ARTICLE technology for pre-incubation treatment of eggs using the drug "Artificial Cuticle" leads to a significant reduction in the number of pathogenic microorganisms on the surface of the shell, which leads to increased hatchability of eggs.

Key words: biotechnology, technology, chitosan, nanotechnologies, egg incubation, disinfectants.

Дата надходження до редакції: 25. 10.2020 р. 